\title{
Notes
}

\section{The Look Within: Property, Capacity, and Suffrage in Nineteenth-Century America}

\author{
Jacob Katz Cogan
}

Wishing to see the trajectory of American history as progressive and democratic, ${ }^{1}$ historians have ignored the complexities of suffrage expansion in the nineteenth century-especially the interrelation of exclusion and inclusion. ${ }^{2}$ This Note looks at the trajectory of suffrage reform from the late eighteenth century to the adoption of the Fifteenth Amendment and argues that reformers were obsessed with the inner qualities of persons. Whereas the eighteenth century had located a person's capacity for political participation externally (in material things, such as property), ${ }^{3}$ the nineteenth century found these qualities internally (in innate and heritable traits, such as intelligence).

1. See, e.g., Chilton Williamson, anerican Sufrkagt from Proptekty to Deniockacy, 17601860 (1960) (offering a narrative of suffrage reform with a progressive bias)

2. Cf. Robert J. Steinfeld, Property and Suffrage in the Early dimencan Republic, \&1 STAN L RtV 335,337 (1989) ("If we adopted [a] whig history of suffrage . we would be radically simplitying a vastly more complex process, and would be engaging in the worst kind of ahistoncal thinking ") There is no intellectual history of American suffrage General histones include MARCHETTE. CHUTt. THE. FIkST LIBERTY: A HISTORY OF THE RIGHT TO VOTE IN AMERICA. 1619.1850 (1969). KIKX HakULI) PUKTER. A HISTORY OF SUFFRAGE IN THE UNITED STATES (1918); and WILLAAMSON, supra nute I Spcoldlued studies are divided by period and topic, and will be referred to infra. For shon. introductury essdys on the history of voting, see VOTING AND THE SPIRIT OF AMERICAN DEMOCRACY (Dunald WV Rugers od . 1992)

3. Kenneth Greenberg has used the word "superticial" to describe the penthanl ut antebellum southerners to be "concerned, to a degree we would consider unususl, with the surtate of things-with the world of appearances." Kenneth S. Greenberg. The Nose. the Lee, and the Duel in the Antebellun South. 95 AM. HIST. REV. 57, 58 (1990). These same persons would be the staunchest delenders of properiy qualifications, discussed infra in Section I.B

4. Qualifications for office holding and jury service followed this same path, thuugh the latter olten lagged. See Alben W. Alschuler \& Andrew G Deiss. A Brief Histon of the Crumunal Jun in the Unuted States, 61 U. CHI. L. REV. 867, 876-901 (1994). Intellectual histonies of the seicnulic basis of intelligence

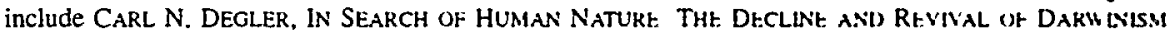
IN AMERican SOClal ThOUght (1991); and John Samuel Carson. Talents. Inielligence. and the Constructions of Human Difference in France and Americd. 1750-1920 (1994) (unpublishod Ph D dissertation, Princeton University) (on file with the Princeton Universily Libran) See also Wakkex SUSMAN, "Personality" and the Making of Thenteth-Centun Culture, in CLLTLke as Histoky 271. 272 (1984) ("Impulses that control human behavior and desuny were felt to arise mure and more wilun the 
Both enfranchisement and disenfranchisement reflected this change of perspective, this look within. ${ }^{5}$

To chart the transformation, this Note examines the debates over suffrage in the state constitutional conventions of the late eighteenth and nineteenth centuries, as well as contemporaneous commentaries. Between 1787 and 1861 every state in the Union convened a constitutional convention in order to create a new constitution or revise an old one. ${ }^{6}$ This intense period of constitutional change seldom gets the attention it deserves, partly because the Federal Constitution casts such a long shadow and partly because the scattered state conventions lack the same presence across time and space. Even so, it was inside and outside these conventions that the constitutional texts of the eighteenth century underwent revision; their assumptions questioned, abandoned, and replaced; the very meaning of American democracy defined. Many of these conventions allowed stenographers to listen, transcribe, and publish their debates, permitting their constituents and delegates in future conventions in other states to listen in and call upon the words of those who went before them. These words were repeated in pamphlets and newspaper and magazine articles, in effect creating a national conversation that spanned decades. It is over the course of this long conversation that we can detect the perspectival change discussed here. ${ }^{7}$

This Note is more interested in describing a change in the normative perspective of nineteenth-century constitutional thought than in explaining the "instrumental" motives of the individual actors whom it highlights. ${ }^{8}$ Such motives are important, but they do not explain why certain outcomes were

individual [as the world became more modern].").

5. This Note does not discuss three important restrictions on the suffrage: residency requirements and the disenfranchisement of both U.S. military personnel and nonresident students. The Supreme Court has held that residency requirements that seek to maintain informed voting do not further any compelling statc interest. See Dunn v. Blumstein, 405 U.S. 330, $359-60$ (1972). Similarly, in Carrington v. Rash, 380 U.S. $89,96-97$ (1965), the Court held that the permanent presumption of nonresidence for voting by military personnel was not reasonable in light of its stated purposes and was therefore unconstitutional. The effect of duration-of-residence and domicile restrictions on student voters is discussed in, for example, Kenneth J. Guido, Jr., Student Voting and Residency Qualifications: The Aftermath of the Twenty-Sixth Amendment, 47 N.Y.U. L. REv. 32 (1972); Rakesh C. Lal, What Jolmny Didn't Learn in College: The Conflict over Where Students May Vote, 26 BEvERLY Hills B. Ass'N J. 28 (1992); Joseph A. Bollhofer, Comment, Disenfranchisement of the College Student Vote: When a Resident Is Not a Residen, 11 FokDHAM URB. L.J. 489 (1983); Paul R. Rentenbach, Comment, Student Voting Rights in University Communities, 6 Hakv. C.R.-C.L. L. REV. 397 (1971); and Christopher J. Reynolds, Comment, State Residency Requirements for Purposes of Voting: The Eligibility of Students To Vote in Their College Communities, 21 AM. U. L. RBv. 774 (1972).

6. See Alben L. Sturm, The Development of American State Constitutions, 12 Publius 57, 82 tbl.5 (1982).

7. For introductions to the antebellum state conventions, see JAMES WILLARD HURST, THE GROWTH of American LaW: THE LAW MAKers 199-246 (1950); and Christian G. Friti, The American Constitutional Tradition Revisited: Preliminary Observations on State Constitution-Making in the Nineteenth-Century West, 1994 RUTGERS L.J. 945.

8. For a recent review of the uses of intellectual history in legal history, sec William W. Fisher IIt, Texts and Contexts: The Application to American Legal History of the Methodologies of Intellectual History, 49 STAN. L. REv. 1065 (1997). On the method applied in this Note, sec $i d$. at 1068. 
desirable (or even possible) at any particular moment, nor do they tell us why once solid political positions eventually turned to mush. Attention to language does not deny the instrumental motives of individual actors. Just the opposite. A speaker's intention to communicate and convince must be presupposed; it is the intention that allows the historian to take the speaker's words seriously (which is different from taking them at face value). ${ }^{*}$ At any moment in history, actors use and invent certain words and arguments because those utterances uniquely resonate at that place and time with their intended audience, resolving the contradictions of the surrounding world in ways other words and arguments simply cannot. ${ }^{10} \mathrm{~A}$ conclusion that the language of the look within simply perpetuated old status relations in new skins ${ }^{13}$ would ignore the significance of the fight itself to the contestants, if not also the changes (however modest) that resulted. ${ }^{12}$

Part I will describe the external view that characterized the eighteenth century, and how its explanatory force gradually faded. Par II will describe the creation of the internal view, how it led to manhood suffrage, and how, at the same time, it continued to disenfranchise women and blacks. Par III will offer a brief conclusion, tying in some additional categories of excluded persons and exploring the limits of the look within.

\section{THE EXTERnAL VIEW}

\section{A. Imagining the People}

The crux of the Constitution's successful unification of a diverse country was its implementation of the invitingly vague concept of popular sovereignty on a national scale. ${ }^{13}$ The people would rule, and rule actively. But if this

9. See Quentin Skinner, Monves, Intentons and the Interpretation of Texts, In Mtaviso avb) CONTEXT: QUENTIN SKINNER AND HIS CRTICS 68, 95 (James Tully dJ. 1988,

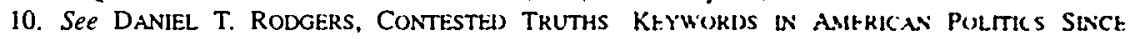
INDEPENDENCE 6 (1987) ("We use words, and we are used by words"), I QurTtw SKaNkt. THk FOUNDATIONS OF MODERN POLTICAL THOUGHT al xil-xill (1978) (posiung that a persun cannul simiply "tailor[] his normative language in order to fit his projects." but that such a persun "must [alsu] [allurl] his projects in order to fit the available normatuve langudge")

11. A number of historians have recently reached this concluston aboul athet irhacentury legal reforms. See, e.g., Reva Siegel, Why Equal Protection No Longer Protects The Eivilung Forms of Status. Enforcing State Action, 49 STAN. L. REV. 1111, 1148 (1997) (asking "lo whtt extent hale these chunges in our practices disestablished histoncally entrenched systems of socisl stratiliction")

12. As Hendrik Hanog has wntten, "Reform may have been lor the most pant symbulk Yet, the symbols had potency." Hendrik Hartog, Lawyering. Husbands Rigits, and "fhe Cinwritten Lu' in Nineteenth-Century America, 84 J. AM. Hist. 67, 95 (1997)

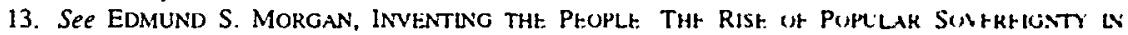
ENGLAND AND AMERICA (1988): GORDON S WOOD. THE CREATION (OF THE AMrHICAN RrPLBLIC, 1776. 1787, at 344-89 (1969); Akhil Reed Amar, The Central Meammg of Republicam Conernment Popular Sovereignn; Majoring Rule, and the Denommator Problem. 65 U Colo L Rt 749. 7.49.52 (1944). Christian G. Fritz, Alternatu'e Visions of American Constutuonaltsm Popular Seneretgun and the Earl, American Constitutional Debate, 24 HASTINGS CONST LQ 287 (1997). Juhn M Murnn, A Roof Whiluus

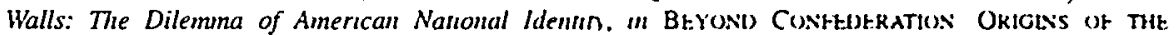


process of accepting the concept of "the people" was complete, ${ }^{14}$ the more dangerous course of imagining who constituted "the people" had barely begun.

That was left to the states. In the name of conciliation and practicality, the federal constitutional convention recognized that " $[t]$ he right of suffrage was a tender point.... The States are the best Judges of the circumstances \& temper of their own people."15 Pierce Butler of South Carolina noted that "[t]here is no right of which the people are more jealous than that of suffrage." J6 James Madison, in The Federalist Papers, concurred: "To have reduced the different qualifications in the different States to one uniform rule would probably have been as dissatisfactory to some of the States as it would have been difficult to the convention." ${ }^{.17}$ So the delineation of the nuts and bolts of political participation-suffrage, representation, apportionment, and citizenship itself-devolved almost entirely upon state legislatures or, more often, upon constitutional conventions. ${ }^{18}$ Inside and outside these forums, the idealized fiction of popular sovereignty met its uncertain reality. There, the uncomfortable question was asked again and again: Who are the people?

\section{B. Property and Suffrage}

When the Federal Constitution was ratified in 1788 , nearly every state required some form of property ownership to qualify for the vote. ${ }^{19}$ Most often this requirement rested on ownership of a freehold estate. ${ }^{20}$ The

CONSTITUTION AND AMERICAN NATIONAL IDENTITY 333 (Richard Beeman et al. cds., 1987).

14. That is, the acceptance of popular political behavior became accepted as normative. On the process of accepting the concept of "the people," see RICHARD BUEL, JR., SECURING THE REVOLUTION: IDEOLOOY IN AMERICAN POLITICS, 1789-1815 (1972).

15. 2 THE RECORDS OF THE FEDERAL CONVENTION of 1787, at 201 (Max Farrand ed., rev. ed. 1937) (statement of Oliver Ellsworth).

16. Id. at 202 (statement of Pierce Butler).

17. THE FEDERALIST No. 52, at 326 (James Madison) (Clinton Rossiter ed., 1961).

18. Article I, Section 2 of the Federal Constitution was one of the few exceptions to this general pattern of delegation. See U.S. CONST. art. I, $\$ 2$ (providing suffrage and apportionment requirements for congressional elections). Congress also received the power of naturalization. See id. $\$ 8$. See generally James H. KeTtNer, The DevelopMENT OF AMERICAN CITIZENSHIP, 1608-1870 (1978) (cxamining the sources of American citizenship); ROGERS M. SMITH, CIVIC IDEALS: CONFLICTINO VISIONS OF CITLEENSHIP IN U.S. HISTORY (1997) (tracing the illiberal character of American citizenship laws up to the early 20th century).

19. For a detailed list of state constitutional provisions pertaining to the suffrage, see WILLI PAUL ADAMS, THE FIRST AMERICAN CONSTITUTIONS: REPUBliCAN IDEOLOGY AND THE MAKINO OF THE STATE CONSTITUTIONS IN THE REvOlUTIONARY ERA 293-307 (Rita Kimber \& Robert Kimber trans., Universily of N.C. Press 1980) (1973). Histories of the suffrage in colonial and revolutionary America include: CORTLANDT F. Bishop, History OF Elections IN THE AMERICAN Colonies 46-98 (Studies in History, Econ. \& Pub. Law Vol. III, No. 1, New York, Columbia College 1893); ROBERT J. DinkIN, Votino IN Provincial AMERICA: A Study OF Elections IN THE THiRTEen COLONIES, 1688-1776, at 28-49 (1977); ROBERT J. DINKIN, VOTING IN REVOlutionary AMERICA: A STUDY OF EleCTIONS IN THE ORIOINAL THIRTEEN STATES, 1776-1789, at 27-43 (1982); and ALBERT EDWARD MCKINLEY, THE SUFFRAOB FRANCHISE IN THE THIRTEEN ENGLISH COLONIES IN AMERICA (1905).

20. See Williamson, supra note 1, at 5. See generally DREW R. MCCOY, THE Elusive Republic: POLITICAL ECONOMY DN JEFFERSONIAN AMERICA 67-69 (1980) (situating property within the ideology of classical republicanism); Chester E. Eisinger, The Freehold Concept in Eighteenth-Century American 
advantage of a freehold was twofold. First, a freehold demonstrated a permanent interest in the community. Second, a freehold proved a person's disinterestedness and independence. As Blackstone wrote, "The true reason of requiring any qualification, with regard to property, in voters, is to exclude such persons as are in so mean a situation that they are esteemed to have no will of their own."2l John Adams agreed, noting that "[s]uch is the Frailty of the human Heart, that very few Men, who have no Property, have any judgment of their own."22 Some states also allowed a cerain net worth to serve as an alternative qualification to a landed interest. ${ }^{23}$ Either way, the requirements sought to insure virtue amongst the electorate and its representatives. To this end, some colonies supplemented the freehold with religious qualifications. ${ }^{24}$ Others excluded persons on the basis of $\operatorname{sex}^{25}$ and race. ${ }^{26}$ But these last two restrictions were articulated less frequently, if only because (as a consequence of coverture or slavery) they were so often subsumed within the freehold qualification itself.

By the early nineteenth century, with a new market society taking shape, ${ }^{27}$ property was not the stable force it once had been. Now prized for its malleability and productivity, property no longer connoted the qualities that had made it synonymous with virtue and independence. ${ }^{28}$ The assault on the freehold qualification, the paragon of trust for the old order, would not be far behind.

Propped up by supports that were no longer stable, the justification for freehold qualifications would gradually collapse. ${ }^{29}$ Every state admitted to the Union after the ratification of the Constitution, save one, ${ }^{30}$ rebuffed a property

Letters, 4 WM. \& MARY Q. 42 (1947) (descnbing the "Jeffersonian Myth" and its emphasis un the moral value of land ownership).

21. I William Blackstone, Commentaries $* 170$

22. Letter from John Adams to James Sullivan (May 26, 1776), in 4 PApers of JOHא ADAMs 208. 210 (Roben J. Taylor ed., 1979); of. WOOD. supra note 13. at 168-69 (setung out the class bras of even some of the more radical Revolutionanes).

23. See, e.g., DEL. CONST. of 1776, ant. V; MASS. CONST pt 2, ch. 1. \$3. an IV (1780) (amended 1821); N.J. CONST. of 1776, an. IV; N.Y. CONST. of 1777, an VIl (applying only to assemblymen)

24. Catholics were disenfranchised in Maryland and New York dunng the colunal period, nonChristians (specifically Jews) were disenfranchised in Maryland. New York. Rhode Island, and South Carolina. See WILLIAMSON, supra note 1, at 15-16. After the Revolution, only the South Carolina constitution retained a clause that required voters to recognize the existence of God See S C CONST of 1778 , art. XIII.

25. New Jersey was the Ione exception to the exclusion of women from the sulfrage See Judith Apter Klinghoffer \& Lois Elkis, "The Petricoat Electors": Women's Suffrage in New Jersev. 1776.1807. 12 J EARLY REPUBLIC 159 (1992).

26. Free blacks were disenfranchised in Georgia. South Carolına. and Virginia See Wiuluusox. supra note 1 , at 15 .

27. See Gordon S. WOOd, THE RAdICALISM OF THE AMERICAN REVOLUTION 311.18 (1992)

28. See Morton J. Horwitz, The Transformation of AMERICAN LaW. 1780-1860, al 31.62 (1977); JAMES WILLARD HURST, LAW AND THE CONDTIONS OF FREEION IN THE NDNETEENTH-CENTURY UNITED STATES 25 (1956).

29. See infra Section II.A.

30. In its 1796 constitution, Tennessee adopted a nominal frechold requirement The frechold could be of any size. See TENN. CONST. of 1796. an. IlI. $\S 1$ 
requirement; and of the original thirteen states, Maryland, New Jersey, and South Carolina eliminated their restrictions in the years between the ratification of the Constitution and the War of $1812 .^{31}$ But the landowners and wealthy merchants who retained political power, particularly the plantation owners of eastern North Carolina and Virginia, and the rural landowners of Connecticut, Massachusetts, New York, and Rhode Island, did not go gently. ${ }^{32}$ While a number of states would retain property requirements for white men after $1830,{ }^{33}$ the conventions of the $1810 \mathrm{~s}, 1820 \mathrm{~s}$, and $1830 \mathrm{~s}$ marked the culmination of the attack on property that had begun in the eighteenth century.

Confronted with this challenge, property defenders held onto their power ever more tightly and devised new theories of government to legitimate old political structures. They did so by refashioning the very logic of corruption and self-interest that had undermined their rule into a new political theory of interests. ${ }^{34}$ Property defenders contended that there were two interests in society, personal rights and property rights, each "indispensable to every movement of Government."35 Property represented a "peculiar interest" and therefore required an "authority proportioned to that interest and adequate to its protection." ${ }^{36}$ This goal could be accomplished in several ways: by a freehold suffrage requirement to vote for representatives to either or both houses of the legislature, by a freehold requirement for office holding, or by the inclusion of property in the formula of legislative apportionment (in a

31. See MD. CONST. of 1776, amends. 12 \& 14 (1810); S.C. CONST. of 1790, art. $1, \S 4$ (1810); Act of Nov. 16, 1807, 1811 N.J. Laws (Bloomfield) 33 (amended 1875).

32. These states held constitutional conventions as follows: Connecticut in 1818; Massachusetts in 1820-1821; New York in 1821; North Carolina in 1835; Rhode Island in 1824; and Virginia in 1829-1830. See Sturm, supra note 6 , at 82 tbl.5.

33. North Carolina dropped its freehold requirement for voting for governor in 1835, but retaincd one for the election of senators until 1857. See N.C. CoNST. of 1835 , art. I, $\$ 3$ (1857) (senators); $i d$. ant. II, $\$ 1$ (governor); Thomas E. Jeffrey, "Free Suffrage" Revisited: Party Politics and Constitutional Reform in Antebellum North Carolina, 59 N.C. HIST. REv. 24, 25 n.3 (1982). Rhode Island stubbornly kept its restrictions until the onset of civil strife in the Dorr Rebellion in 1842. See R.I. CoNST. art. II, $\S \S 1-2$ (1842) (amended 1888) (providing an alternative to the property qualification). See generally PATRICK T. CONLEY, DEMOCRACY IN DECLINE: RHODE ISLAND's CONSTITUTIONAL DEVELOPMENT, 1776-1841 (1977); George M. DENNISON, The DorR War (1976); MARVIN E. GeTtleman, THE DORR Rebellion (1973). Tennessee dropped its freehold requirement in 1834. See TENN. CONST. of 1834, art. IV, \& 1. Virginia eliminated its freehold requirement in 1851 . Compare VA. CONST. of 1830 , art. III, $\S 14$ (elaboriting the freehold qualifications), with VA. CONST. of 1851, art. III, $\$ 1$ (eliminating the frechold requirement). See generally WILLIAM G. SHADE, DEMOCRATIZNG THE OLD DOMINION 278 (1996).

34. This section focuses on the constitutional conventions of Connecticut, New York, and Virginia. On these conventions, see, respectively, RiCHARd J. PURCELl, CONNECTICUT IN TRANSITION, 1775-1818, at 236-64 (Wesleyan Univ. Press 1963) (1918); John Antony Casais, The New York State Constitutional Convention of 1821 and Its Aftermath (1967) (unpublished Ph.D. dissertation, Columbia University) (on file with the Columbia University Library); SHADE, supra note 33, at 50-77; and ROBERT P. SUTTON, REVOLUTION TO SECESSION: CONSTITUTION MAKING IN THE OLD DOMNNION 72-102 (1989).

35. Proceedngs and Debates of the VIRGinia State Convention of 1829-30, at 71 (Richmond, Samuel Shepherd \& Co. 1830) [hereinafter VIRGINIA CONVENTION OF 1829-1830] (statement of Abel Parker Upshur).

36. Id. 
similar fashion to the U.S. Constitution's Three-Fifths Clause, ${ }^{37}$ which defined the apportionment of the House of Representatives).

Advocates of property representation did not impute evil motives or wickedness to those without propenty, only envy. "[A]s all men know now." Richard Morris explained, "unless property is protected, it will be invaded." The principle of government, this theory stressed, should "not [be] confidence, but jealousy and watchfulness" of persons." Only fools, argued Benjamin Watkins Leigh, would base a government on "the moral sense of mankind" when "self-love is the great spring of human actions." Even "the highest degree of moral virtue, the most pure and unblemished integrity, and ... sublime intelligence, afford us no adequate protection: for men always have differed, and always will differ, in questions involving great and expensive objects of national enterprize."4l If the power to determine taxation and appropriations were given to those who did not contribute their own earnings, "they may ... destroy those from whom it is thus unjustly taken."'? In short, because government acted on the interests of persons and propenty, each of these interests should be represented in government. ${ }^{4 i}$

The dangers that motivated the proponents of the interest theory of government were far from illusory. In the southern states, plantation owners feared that representation and suffrage devoid of a property requirement would give control of the legislatures to westerners who, desperate for new markets for their goods, would raise taxes on eastern plantations in order to fund massive internal improvement projects. ${ }^{\text {it }}$ In the northern states, farmers feared that manufacturers would manipulate their workers to outvote the agricultural interests. The "manufacturing population must be mo[r]e ignorant, and more subject to an arbitrary or corrupt influence" than farmers, Jacob Sutherland of

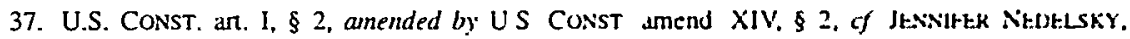
PRIVATE PROPERTY AND THE LIMITS OF AMERICAN CONSTITUTIONALISM (19\%) (articulating the udys in which private property was protected at the Founding)

38. VIRGINIA CONVENTION OF 1829-1830, supra nole 35, at 111 (stutement of Richard Mfurris), see also Journal of Debates and Proceedings in the Convention of Deligates. Chosten To Rt.yist THE CONSTITUTION OF MASSACHUSETTS (Boston, Boston Dally Advertiser rev od 1853) (hercinafter MASSACHuSETtS CONVENTION OF 1820-1821] (statement of Daniel Webster) ("[l]t is enturely just that property should have its due weight and consideration in polutucil arrangements ")

39. ViRginia CONVENTION OF 1829-1830, supra note 35, at 113 (statement of Richard Mlortis)

40. Id. at 167 (statement of Benjamin Watkins Leigh)

41. Id. at 114 (statement of Richard Morns).

42. Id. at 158 (statement of Benjamın Watkans Leigh), see also NOAH Wt:BSTtK. JH. Ax OKATIOS.

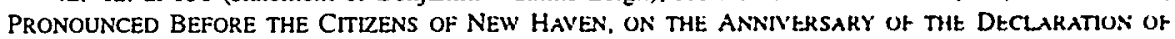

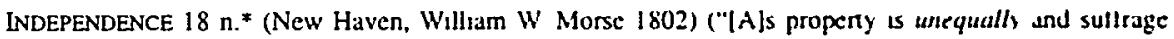
equally divided, the principle of equal suffrage becomes the basis of inequalin of power ")

43. See Virginia Convention of 1829-1830, supra note 35, at 98 (statement of Philip P Barbour). id. at 205-16 (statement of Thomas Joynes).

44. See SutTon, supra note 34, at 128-29; see also. e g. Harold J Counihan. The North Carolina Constitutional Con'ention of 1835: A Study in Jacksoman Democracy. 46 N C HisT REV 335. 347.62 (1969). 
New York asserted in $1821 .^{45}$ Workers "were liable to sudden, violent, and dangerous excitements" and, as "all classes of the lower orders of society[] are more or less subject to influence," they were easily manipulated. ${ }^{46}$ Not knowing better, workers "look with something of deference and respect to the opinions of those who employ them, who consequently minister to their comfort or subsistence." 47

But the property-based theory of government was not simply utilitarian; property, for its advocates, continued to be the best test of character, just as it had been in the eighteenth century. While it "conferred upon its possessor neither virtue, integrity, or talents," Ezekiel Bacon declared in New York's convention, "it could not be disguised that ... it was a safe general rule that industry and good habits did in almost every instance conduct the man that practiced them, to some moderate share of property, and to a small competence, which only he would require." ${ }^{.48}$ If not a foolproof technique, the property qualification, he said, "furnished the most probable test of character, and the greatest likelihood of finding united with it independence, sobriety, and safe intentions." ${ }^{29}$ Landholders, wrote David Daggett of Connecticut, "have too much self respect to endure the slightest approaches to slavery-they have too much at stake to tolerate anarchy." ${ }^{250}$ Other defenders of the property qualification argued that the reverse was true as well: The absence of property, Warren Dutton of Massachusetts said in 1820, indicated that a person was either "indolent or vicious." 51 "In every commercial society," Henry Ford of New Jersey argued in 1806, "wealth is the measure of respectability, and the foundation for that spirit of independence absolutely essential to unbiassed elections." 52

If nothing else, property defenders insisted, the consequences of suffrage expansion and equal representation were unknown, and therefore expediency demanded careful and deliberate scrutiny. The suffrage, they said, was entirely arbitrary; therefore, "[i]f it can be limited any where ... it is a question of expediency at what point it shall be fixed." ${ }^{\text {"53 }}$ As there was no telling how

45. REPORTS OF THE PROCEEDINGS AND DEB ATES OF THE CONVENTION OF 1821, ASSEMBLED FOR THB PuRPOSE OF AMENDING THE CONSTITUTION OF THE STATE OF NEW-YORK 281 (Albany, E. \& E. Hosford 1821) [hereinafter NEW YORK CONVENTION OF 1821] (statement of Jacob Sutherland).

46. Id.

47. Id.; see also MASSACHUSETTS CONVENTION OF 1820-1821, supra note 38, at 251 (statement of Josiah Quincy) ("[T]he rich [person], by the influence resulting from his property over the class of paupers, has a power of indemnifying himself a hundred fold.").

48. NEW YORK CONVENTION OF 1821, supra note 45, at 285 (statement of Ezekiel Bacon).

49. Id.

50. David Daggett, facts are Stubborn Things, or NIne Plain Questions to the Peoplb of CONNECTICUT 20 (Hartford, Hudson \& Goodwin 1803).

51. MASSACHUSETTS CONVENTION OF 1820-1821, supra note 38, at 247 (statement of Warren Dutton).

52. HENRY Ford, AN ORATION, DELIVEREd IN THE PRESBYterian ChURCH AT MORRIS-TOWN, JULY

4, 1806, at 8-9 (Morristown, Henry P. Russell 1806).

53. A Freeman, ConN. COURANT, Sept. 29, 1818, at 2. 
dangerous universal suffrage might be, it was best to ent on the side of safety. ${ }^{54}$ And so, while the property qualification was "not perfect, [it was] the best human wisdom can devise. It affords the strongest, if not the only evidence of the requisite qualifications; more particularly of what are absolutely essential, 'permanent common interests with, and attachment to, the community." "55

\section{THE LOOK WITHIN}

These sentimental visions of agricultural life failed to convince the disenfranchised and unrepresented. For one, the property holders' purported fear of the manufacturing interests seemed overstated because the difference between the landholder and the manufacturer was no longer as clear as it once might have been. Was not the "powerful manufacturer . . connected with the landed interest? Is not the manufactory itself real estate?" asked Erastus Root of New York. ${ }^{56}$ If so, "[p]roperty [would] always carry with it an influence sufficient for its own protection." $\$ 37$ Therefore, there was no danger that manufacturing, commerce, and labor would combine to destroy agriculture.

Critics claimed the opposite was true, namely that money, in the form of property, corrupted. And though it was commonly "thought . . that poverty and vice are identified," the contrary, "more integrity and more patriotism are generally found in the labouring class of the community than in the higher orders." ${ }^{\text {"Sy }}$ One simply had to "look to the higher classes of society ... . [to] discover the grossest abuse of wealth." Land title failed to "contribute to the elevation of the mind, or [to give] stability to independence, or [to add] wisdom to virtue." Nor did it give "any evidence of peculiar merit, or superior title," a group of Virginia non-freeholders asserted. ${ }^{62}$ In fact, they contended, "were it not for the gravity with which the proposition is maintained, and still more, for the grave consequences flowing from it" the ascription "to a landed possession, [of] moral or intellectual endowments, would truly be regarded as ludicrous." ${ }^{63}$ Land, they said, "no more proves him who has it, wiser or

54. See R., Connecticul Convention, CONN Courant, Sept 22, 1818, al 3

55. VIRGINLA CONVENTION OF 1829-1830, supra note 35. it 27 (Memonal of the Non-Frecholders of the City of Richmond) (paraphrasing the arguments of their opponents)

56. NEW YORK CONVENTION OF 1821, supra note 45, at 223 (statement of Erastus Root)

57. Id. at 225 (statement of Jacob Radcliff).

58. Id. (statement of P.R. Livingston).

59. Id. at 239 (statement of John Cramer).

60. Id. at 225 (statement of P.R. Livingston).

61. Id.

62. VIRGINIA CONVENTION OF 1829-1830, supra note 35, at 27 (Memonal of the Non-Frecholders of the City of Richmond).

63. Id. 
better, than it proves him taller or stronger, than him who has it not." ${ }^{64}$ Benjamin Austin of Massachusetts wondered why men must wait "till they have turned their intelligence into stock" in order to get the vote. ${ }^{65}$ There was no proof "that the States in wh[ich] a property qualification is established, either choose wiser men, or are less democratical than those States where the property qualification for electors does not exist," admitted even propertydefender Rufus King. ${ }^{66}$ Property, "experience has shewn[,] . . forms not the scale of worth," P.R. Livingston asserted, "and . . character does not spring from the ground." 67

This skepticism in the attributes of property led Americans to search elsewhere for the location of the qualities necessary to vote. So, disillusioned with the adequacy of external characteristics as indicators of virtue, they looked inward. Section II.A traces the gradual realization during the first decades of the nineteenth century that these characteristics were to be found within all white men. Sections II.B and II.C show how white men delimited this discovery by sex (by asserting a distinct familial role for women) and race (by asserting the uncultivated nature of the minds of black men).

\section{A. Manhood Suffrage}

Since property ownership could not be counted upon to guarantee independence and virtue, that qualification quickly turned into one of many ways to demonstrate a stake in society. By the 1790 s, some Americans had already begun to explore the limits of this revelation. ${ }^{68} \mathrm{~A}$ stake in society, they noticed, did not have to be immovable; a demonstrable interest or meaningful contribution could suffice. Any person who gave, in one way or another, to the administration of the state should earn the vote. "Does not the adventurous mechanic, who ... turns himself with steady industry to the pursuits of the occupation in which he has been bred, give sufficient 'evidence of permanent common interest with, and attachment to the community'?" asked Virginia state senator William Munford in $1801 .{ }^{69}$ "[T] hose who bear the burthens of the state," Nathan Sanford argued in the New York constitutional

64. Id.

65. MASSAChuSetTS CONVENTION OF 1820-1821, supra note 38, at 252 (statement of Benjamin Austin).

66. Letter from Rufus King to Christopher Gore (Dec. 18, 1820), in 6 THE LIFE AND CORRESPONDENCE OF RUFUS KING 365, 365-66 (Charles R. King ed., 1900).

67. NEW YORK CONVENTION OF 1821, supra note 45, at 225 (statement of P.R. Livingston); see also MASSACHUSETTS CONVENTION OF 1820-1821, supra note 38, at 253 (statement of Joseph Richardson) ("Want of property in a free government, should be the last thing to prevent men from voting, unless the possession of property were shown to be necessarily connected with virtue.").

68. See Marc W. Kruman, Between Authority and Liberty: State Constitution Makino in REVOLUTIONARY AMERICA 92-95 (1997).

69. A Citizen, To the Citizens of Riclumond, Not Freeholders, VA. ARgus (Richmond), July 31, 1801. reprinted in THE FAITH OF OUR FATHERS 14, 15 (Irving Mark \& Eugene L. Schwaab eds., 1952). The author of this article was William Munford. See THE FATTH OF OUR FATHERS, supra, at 14. 
convention of 1821 , "should choose those that rule it."70 Thus, he continued, "[t]here is no privilege given to property, as such; but those who contribute to the public support. we consider as entitled to a share in the election of rulers."71 The rallying cry of the Revolution, "no taxation without representation," became the mantra of manhood suffrage proponents."

But the taxpaying qualification, first instituted in Pennsylvania's constitution of $1776^{73}$ and subsequently adopted by a number of states, was not the only way to demonstrate the requisite stake in society. It was unclear to some why monetary contributions to the state "confer[red] a better claim to political power than those of any other description." "7s Why, for instance, should taxes take priority over "personal services" such as militia duty? "He who devotes the energies of his body and mind to the welfare of his country, labours to promote her best interests, or defends her rights upon the battle field, may surely claim the merit of having contributed to the support of Government," argued one suffrage advocate. " Samuel Young, in New York's constitutional convention, pointed out that those who performed militia service "really paid a heavier tax than many freeholders of \$2000." In sum, "[n]o reason can be assigned, why those who bear the public burthens, either by defending the soil, or by contributing to the support of government, should not be entitled to exercise the elective franchise."79 Similarly, the Niles' Register concluded that, "As a general principle, then, we hold it to be equitable, that every citizen who may be called into the military service ... or who is liable to a [tax] should have the right [to vote]." who worked the public highways deserved the vote. ${ }^{81}$ The logic implied that "[a]Il are bound to contribute to the support of Government according to their

70. NEW YORK CONVENTION OF 1821, supra note 45, al 178 (statement of Nathan Sanford).

71. Id.

72. E.g., id. at 257 (statement of Martin Van Buren)

73. See PA. CONST. of 1776. $\$ 6$. The taxpaying provisions were relitined in Pennsylvania's later constitutions. See PA. CoNST. of 1838, an. III. $\$ 1$. PA CoNST of 1790. an III. $\$ 1$

74. See, e.g., CONN. CONST. of 1818 , ant. VI, $\$ 2$ (giving alternatwe suffrage rexumements of frechold. tax, or militia service); DEL. CoNST. of 1792, ar. IV. $\S 1$; GA CONST of 1798, an IV. $\$$ I. LA CoNST of 1812 , art. II, $\$ 8$ (establishing taxpaying as an alternatuve to a propeny requirement); Mass CoNsT amend. III (1821) (amended 1891); MISS. CONST. of 1817. an III, $\$ 1$ (giving alternatuve suffrage requirements of militia service or tax); N.H. CONST of 1784. pl II: NY CoNsT of 1822. an II. $\$ 1$ (giving altemative suffrage requirements of milua senice, tax, or public highway duty); $\mathrm{NC}$ CONST of 1776, art. VIII (applying to assemblymen only): OHIO CONST of 1802. ant. IV. $\$$ I. R I CONST an. II. \$ 2 (1842) (amended 1888) (giving a taxpaying altematuve in leguslatuve elections to the frechold suffrage requirement for native-born citizens); S.C. CoNST of 1790 , an $1 . \S+$ (giving a taxpaying alternative to the freehold suffrage requirement). All of these provisions were revoked by 1902

75. VIRGINIA CONVENTION OF 1829-1830, supra note 35, at 101 (statement of Bnstoc G Baldwin)

76. Id.

77. Id.

78. NEW YORK CONVENTION OF 1821, supra note 45, at 274 (statement of Samuel Young)

79. Franklin, The Constitution, AM. MERCURY (Harford). Sept 29. 1818. at 3

80. The Right and Power of Suffrage, 19 NiLEs' REG (Baltumore) 115. 115 (1820) (cmphusis omitted)

81. New York's constitution of 1822 provided for just that See $N Y$ CONST of 1822, ast II. I (giving altemative suffrage requirements of milita service, lax. or public highway duty) 
means [and] all are entitled to the right of suffrage who have sufficient evidence of permanent common interest in, and attachment to, the community." 82 Even the remotest civic contribution conceivably could be construed as taxation and thus as ample qualification for the suffrage.

Provoked by these realizations, advocates of suffrage expansion developed by the 1820 s a political theory of human nature to counter the propertyoriented, interest group theory of representation. The new theory postulated that the qualities of independence, virtue, and intelligence-once associated with property ownership - were in fact found within each and every man. "Nature has made no distinction among men," argued James Robertson in the Virginia House of Delegates in $1806 .{ }^{83}$ "Man is man, and it is not within the power of a freehold to change his character." "We give to property too much influence," one New Yorker concluded. ${ }^{85}$ "It is not that which mostly gives independence. Independence consists more in the structure of the mind and in the qualities of the heart." ${ }^{86}$ According to the Virginia non-freeholders, virtue and intelligence were not "the products of the soil" and "[a]ttachment to property [was] not to be confounded with the sacred flame of patriotism." 87 Instead, patriotism was "engrafted in our nature" and "exists in all climates, among all classes, under every possible form of Government." impaired patriotism more often than poverty. ${ }^{89}$ Consequently, "the only effectual guarantee, against the abuse of power in a republic, is to be found, and to be found only, in the virtue and intelligence of the people, in whom all power rests." ${ }^{.90}$

As a consensus emerged that men inherently possessed the qualifications for the vote, property and even taxpaying requirements made less sense. By the 1840s, white manhood suffrage became the norm. ${ }^{11}$ Nothing should "step in between [a man] and the exercise of his natural rights as a citizen," John Simonds of Massachusetts asserted in $1853 .{ }^{92}$ Simply because "accidents of birth or property" ${ }^{\prime 93}$ may have made a man rich or poor did not make him less qualified to govern. The principle was, as Simonds put it, "that a man is a

82. ViRgINia CONVENTION of 1829-1830, supra note 35, at 102 (statement of Briscoe G. Baldwin).

83. Call of a Convention, ENQUIRER (Richmond), Feb. 1, 1806, at 3 (statement of James Robertson in the Virginia House of Delegates debate on the calling of a constitutional convention).

84. Id.

85. NEW YORK CONVENTION OF 1821, supra note 45, at 235 (statement of Daniel D. Tompkins).

86. Id.

87. ViRGINIA CONVENTION OF 1829-1830, supra note 35, at 27 (Memorial of the Non-Frecholders of the City of Richmond).

88. Id.

89. See id.

90. Id. at 107 (statement of Alfred H. Powell).

91. See PORTER, supra note 2, at 110 tbl.; WILLIAMSON, supra note 1, at 260-61.

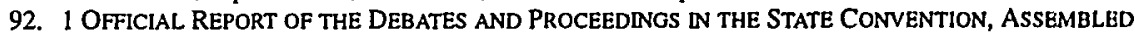
MAY 4TH, 1853, TO REVISE AND AMEND THE CONSTITUTION OF THE COMMONWEALTH OF MASSACHuSETTS 554 (Boston, White \& Potter 1853) [hereinafter MASSACHUSETTS CONVENTION OF 1853] (statement of John W. Simonds).

93. Id. at 566 (statement of Benjamin F. Hallett). 
man; [and] that mind and judgment make a man, instead of fortune or any outward circumstances, of whatever nature." In essence, "the sovereignty of government [was found with]in the man."95

\section{B. Woman Suffrage}

When suffrage rested in property, few questioned the gendered limitations of the vote. 96 Through the system of coverture, as William Jarvis wrote in 1820 , married women simply "confered upon their husbands, by the marriage contract, all their civil rights: not absolutely, . . . but on condition, that the husband will make use of his power to promote their happiness, and the propriety of their children." 97 Because they could not hold property in their own names and because their legal statuses were subsumed in their husbands', married women could not qualify for the suffrage. By this logic, however, it might have seemed that unmarried women or widows deserved elective rights. But, as Jarvis explained, because "it [was] considered, that no practical inconvenience has ever been experienced . . . , and that no possible good could result from conforming the practice of the country, in this particular, to strict theory," even these women were not granted the vote. ${ }^{y s}$ That propertied women lacked the vote, Edward Keyes of Massachusetts stated more than thirty years later, was "one of those accidents and misfortunes which is irremediable directly, but which is amply compensated for in a thousand other ways [and is a small sacrifice to pay] for the good of the rest of the community." 99 Though unmarried propertied women did vote in New Jersey until they were disenfranchised in $1807,{ }^{100}$ men presumed that women really did not desire the vote. ${ }^{101}$

Some argued, however, that women were competent to vote, regardless of their desire to do so. Defenders of the property requirement-eager to point out the inconsistencies in the arguments of manhood suffrage advocates-asserted that women (if they cared to) were just as capable of voting as men. "Can any gentleman shew me a reason drawn from nature," Philip Barbour of Virginia argued, "which subjects females, as such, and

94. Id. at 554 (statement of John Simonds)

95. Id. at 564 (statement of Benjamin F. Hallelt)

96. But see KRUMAN, supra note 68, at 103-16 (noung \& tew persuns who questluned the disenfranchisement of whdows and unmarried properued women in the 177Us)

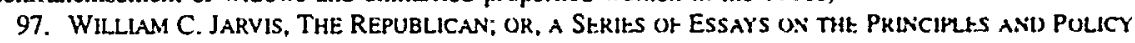
of Free States, having a Particulak Refiekence to the Untrid Statts of allekica and the INDIVIDUAL STATES 66 (Pittsfield, Phineas allen 1820)

98. Id. at 67 .

99. 2 MASSACHUSETTS CONVENTION OF 1853, supra nule 92. di 735 (stulement ol Edward L Keyes)

100. See Klinghoffer \& Elkis, supra note 25, at $159-60$.

101. See, e.g., VIRGINIA CONVENTION OF 1829-1830, supra nute 35. al 227 (stulement ut Samuel M'D Moore) ("Women have never claimed the right to participate in the formation of the Government") 
because of their sex only, to the dominion of men?" 102 An unmarried woman, over twenty-one, he pointed out, was still "in possession of all her rights," and "those rights are by nature the same with those of the other sex." 103 Men "merely as such, have no natural right to exercise any control over her whatsoever." 104 It could "not be contended," Barbour concluded, "that females are to be excluded for the want of capacity." 105

Capacity, however, would prove to be precisely the point of contention and exclusion. Advocates of manhood suffrage based their theory on the capacity of persons, and that capacity, in their view, was distinctly gendered. A woman's mind, they claimed, was "more fit for the sphere in which [God] intended her to act, [and so He] had made her weak and timid, in comparison with man, and had thus placed her under his control, as well as under his protection." 106 Suffrage, John R. Cooke of Virginia argued in 1829, implied exclusively masculine traits such as "free-agency and intelligence; free-agency, because it consists in election or choice between different men and different measures; and intelligence, because on a judicious choice depends the very safety and existence of the community." 107 Women, therefore, had a natural "incapacity to exercise political power."108 According to this view, women's unique - though not necessarily inferior-capacity lay elsewhere: in their own domestic and familial sphere. ${ }^{109}$

Women contested this characterization from the moment it was made. Cooke and his fellow Virginians, for example, were countered by "Virginia Freewoman," who, in a newspaper article published during the convention, questioned the assertion of women's natural incapacity to participate in politics. ${ }^{110}$ In arguments reminiscent of Mary Wollstonecraft's $A$ Vindication of the Rights of Woman," "Virginia Freewoman" took aim at the notion of separate spheres that had already become conventional wisdom: "You boast ... of your superior intelligence of mind-You say, that you alone can exercise the right of suffrage, . . . [but] if we enjoyed greater opportunities of improvement, we too . . . could think, and feel and act for ourselves, in matters

102. Id. at 92 (statement of Philip P. Barbour).

103. Id.

104. $I d$.

105. Id:; see also G.S. Hillard, The Letters of Silas Steadfast, BOSTON COURIER \& ATLAS, 1853 (arguing that the right to vote is based on expediency and not on capacity), reprinted in DISCUSSIONS ON the CONSTITUTION PROPOSED to THE PEOPLE OF MASSACHUSETTS BY THE CONVENTION OF 1853, at 117 . 117-20 (Boston, Little, Brown \& Co. 1854).

106. VIRGINIA CONVENTION of 1829-1830, supra note 35, at 55 (statement of John R. Cooke).

107. Id.

108. Id. (emphasis added).

109. On the concept of separate spheres, see Nancy F. COTT, THE BONDS OF WomanHood: "WOMAN'S SPHERE" IN NEW ENGLAND, 1780-1835 (1977). For an example of the rhetoric of separatc spheres, see infra text accompanying notes 124-130.

110. Virginia Freewoman, The Rights of Women, ENQUIRER (Richmond), Oct. 10, 1829, at 2.

11. Mary Wollstonecraft, a Vindication of THE Rights of WOMAN 223-30 (Miriam Brody ed., Penguin Books 1992) (1792) (discussing the effects of education on development). 
of government, with as much independence as you do."112 By the 1840s, a number of women, disillusioned with the ineffectiveness of their social reform agenda, ${ }^{113}$ joined "Virginia Freewoman" and began to question the separate spheres ideology that shut them out of the political arena. Men. Elizabeth Cady Stanton argued, "fail[ed] in the business they undert[ook]," whether it was "in the pulpit, at the bar, or in our legislative halls." 114 "Now," she continued, "is it to be wondered at that woman has doubts about the present position assigned her being the true one, when everyday experience shows us that man makes such fatal mistakes in regard to himself?"115 If men did not fit within the idealized, ideological confines of their own sphere, why should women?

Not only were the accepted boundaries of men's and women's separate spheres incompatible with reality, women argued, but also the concept of spheres itself was flawed. To justify women's suffrage both women and men asserted the equality of the sexes. In the Massachusetts constitutional convention of 1853, for example, William Greene used manhood suffrage arguments in this way to promote the vote for women. "The people," he argued, "are they upon whom shines that intellectual light which enlightens every man that cometh into the world." 116 Women were just as "capable of receiving [this] intellectual light, [and so] are rational creatures, human beings, enjoying all the faculties which belong to human beings." 117 Woman, Norton Townshend of Ohio said in 1851, "shares equally with man in all the rights that pertain to our common humanity, and . . . I say further that she is man's equal in intelligence and virtue, and is therefore as well qualified as man to share in the responsibilities of government."

If women had the same capacities as men, then they simply had to demonstrate a stake in society in order to qualify for the suffrage as it was then conceptualized. The married women's property acts were crucial in this regard. ${ }^{119}$ "We already have a property law," Elizabeth Cady Stanton wrote in 1856, "which in its legitimate effects must elevate the femme covert into a

112. Freewoman, supra note 110 , at 2

113. On women's gradual recognition of their need and nght to enter the political sphese. see Lok1

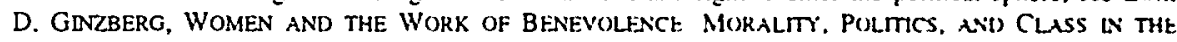
NINETEENTH-CENTURY UNITED STATES 67-132 (1990)

114. Letter from Elizabeth Cady Stanton to George G Couper. Editor. Sahonal Reformer (Sept 14. 1848) [hereinafter Letter to George G COoper], m 2 ELVABETH CA1MY STANTUN AS RFVhalen LN HER LETTERS, DIARY, AND REMINISCENCES 18, 19 (Theodore Stanton \& Hamot Stantun Blalch cols. Amo Press Inc. 1969) (1922) [hereinafter STANTON PAPERS] On Elizabch Cady Stanion and the carly woman sultrage

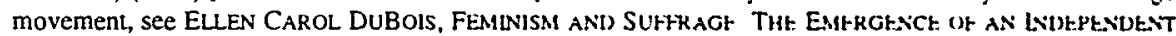
WOMEN'S MOVEMENT N AMERICA, 1848-1869 (1978)

115. Letter to George G. Cooper, supra note 114, in Stanton Papteks, supra nute 114. al 19

116. 2 MASSACHUSETTS CONVENTION OF 1853, supra nole 92. at 726 (stalement of Willam Greene)

117. Id.

118. 2 REPORT OF THE DEBATES AND PROCEEDUNGS OH THH CONVETION FOH THA REVISIOS OH THE CONSTITUTION OF THE STATE OF OHIO, 1850-51. at 555 (Columbus. S Mledan 1851 ) (statement of Nonon Townshend).

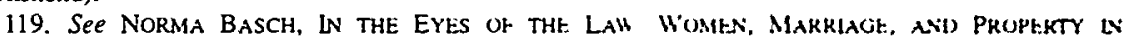
NINETEENTH-CENTURY NEW YORK 197 (1982) 
living, breathing woman - a wife into a property holder, who can make contracts, buy and sell."120 "It needs but little forethought," she continued, "to perceive that in due time these property holders must be represented in the government." 121 Using the familiar manhood suffrage argument of no taxation without representation, six women petitioned the 1846 New York constitutional convention on behalf of woman suffrage. ${ }^{122}$ They argued that the state, "by imposing upon them burdens of taxation, both directly and indirectly, without admitting them the right of representation, [struck] down the only safeguards of their individual and personal liberties."123

Men countered these assertions of women's rights with an intense defense of the ideology of separate spheres. The marriage contract established a family, Abijah Marvin argued in the Massachusetts constitutional convention of 1853:124 "In order to secure the rights of these families-these units, including all the individuals in them, however young, or weak, or imbecile-each family must be represented; must have a voice and a vote in those representative bodies where the laws are made." 125 Why, then, did men represent the family? Because, Marvin contended,

there is a division of labor . . . between labor in the house at home, and labor out of doors; between influences exercised within the family, and without the family; between taking care of the family within the house, and providing for it, and taking care of its interests, by thought, labor, and other exertions, in the fields, the shop, the store, and the assembly. ${ }^{126}$

The distinction between the sexes was ordained by God and had its origins in nature. ${ }^{127}$ The family "can have but one will; and the man, who, by nature, is placed at the head of that government, is the only authorized exponent of that will." 128 Thus, even if women were not confined by their natures to a separate sphere, "it would be a violation of the general rule, that the will of the whole family is represented by the man, who is the head of the family. Politically speaking, therefore, woman has no right to be directly consulted in

120. Letter from Elizabeth Cady Stanton to Gerrit Smith (Jan. 3, 1856), in 2 STANTON PAPERS, silpra note 114 , at 63,63 .

121. Id., in 2 STANTON PAPERS, supra note 114, at 63-64.

122. On this petition, see Jacob Katz Cogan \& Lori D. Ginzberg, 1846 Petition for Woman's Suffrage, New York State Constitutional Convention, 22 Signs 427 (1997).

123. REPORT OF THE DEBATES AND PROCEEDNGS OF THE CONVENTION FOR THE REVISION OF THE CONSTITUTION OF THE STATE OF NEW YORK 646 (Albany, Evening Allas 1846) [hereinafter NEW YORK CONVENTION of 1846] (Memorial of Six Ladies of Jefferson County, Asking for the Extension of the Elective Franchise to Women).

124. See 2 MASSAChusetts CONVENTION of 1853, supra note 92, at 747 (statement of Abijah Marvin).

125. Id.

126. Id. at 748 .

127. See id.

128. Id. at 598 (statement of George Boutwell). 
public affairs." 129 A woman's proper role was as wife and mother, educating her husband and sons with the virtue required of republican citizens. ${ }^{160}$

The look within had created the possibility that women could demand political rights. But the concept of separate spheres effectively, if temporarily, rebutted that claim, asserting that women and men had different capacities: one public and political, the other private and familial. Women would only get the vote at the national level when suffragists turned the language of separate spheres around and argued that a woman's natural qualities made her uniquely qualified to vote. ${ }^{131}$

\section{Black Suffrage}

In 1835, after years of resistance, a convention met to revise North Carolina's constitution. ${ }^{132}$ One of the first items of debate was whether the right to vote should be limited to white men. ${ }^{131}$ Many states had such qualifications already, ${ }^{134}$ but North Carolina, whose constitution dated back to 1776 , did not, and the few free black men who met the general suffrage criteria voted. ${ }^{135}$ Like New York, which had restricted black voting thineen years earlier, ${ }^{136}$ and Tennessee, which had disenfranchised blacks the year before, ${ }^{137}$ North Carolina's move to expand suffrage to all white men led to articulate arguments for black suffrage that were ultimately, but not inevitably.

129. Id. at $598-99$

130. See Ruth H. Bloch, The Gendered Meanngs of Virtue in Reiolutionan Ambriua. 13 Siciss 37. 38 (1987); Jan Lewis, Motherhood and the Construction of the Male Cittern in the Limied Stutrs, 1750 1850, in CONSTRUCTIONS OF THE SELF 143, 155 (George Levine od . 1992)

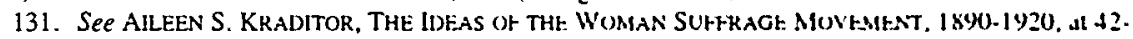
74 (1965).

132. See Counhan, supra note 44. Although this section discusses racial classiflcittons only with regard to blacks, its argument applies equally to the ireatment of Nultve Amencatss and Astan Amenicuns. who were often specifically disqualified as well. See, eg. MiviN CoNst an VII. $\$ 1(1857$ ) (amended 1960) (enfranchising only "civilized" Indians); OR CONST an 11. $\$ 6$ (1857) (repesled 1927) (disyuadilying "negro[es]," "chinam[e]n," and "mullatoles]" (rom the vote)

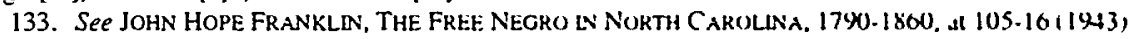
(recounting the discussion of black suffrage in the Nonth Cafolind consututuonal convention of 1835 )

134. See, e.g., ALA. CONST of 1819, ant III. \$ 5. CONN CONST of 1818. ant VI. \$ 2. DiL CUNST of 1831 , art. IV, $\$ 1$; ILL. CONST of 1818, an. II. $\$ 27$, INI) CONST of 1\$16, an VI. \$1. KY CuNsT ul I792, art. III, \& 1; MD. CONST. of 1776, amends 12 \& 14 (1810). MIICH CoNst of Is35. art II. \$1. Miss. CONST. of 1832, art. III, $\$ 1$ : MO CONST of 1820. an III. $\$ 10 . \mathrm{SC}$ COSST of 17\%), an I. \$ 4 . VA. CONST. of 1830, an. III, $\$ 14$; Act of Nor 16.1807. 1811 N J Luws (Bloomheld) 33 amended 1875). J. Stanley Lemons \& Michael A. McKennd, Re.Enfranclusement of Rhode Islant N'rgrues. 30 R I Hist 3 (1971) (discussing the Rhode Island qualificalion, which wis sdopied in 1822 , see also Manun Thompson Wright, Negro Suffrage in New Jerser. 1770.1875. 33 J Nircko Hist 165. 175 (1448) (describing the process of disenfranchisement in New Jersey). of NY CuNst of 1S22. ant II. $\$ 1$ (establishing a propeny requirement spectfic to blacks)

135. See FRANKLN, supra note 133, at 106-08. Counhan. suprat note 4t. at 3-16. Ruget Wallate Shugg, Negro Voting in the Ante.Bellum South. 21 J NtGRo HIST 357. 358 (1936)

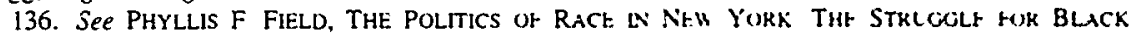
SUFFRAGE IN THE CINIL WAR ERA 29 (1982)

137. See TENN. CONST. of 1834 , an IV. $\$$ I. J W Pallon. The Progress of Emancipanon in Tennessee 1796-1860, 17 J. NEGRO HIST. 67, 72-74 (1932) 
in vain. ${ }^{138}$ The debate on black suffrage would continue until the adoption of the Fifteenth Amendment-in Pennsylvania in 1837-1838, ${ }^{139}$ in New York in $1846,{ }^{140}$ and from then on in conventions, legislatures, and popular referenda throughout the country. ${ }^{141}$ Though only Rhode Island enfranchised its black citizens during the antebellum period, ${ }^{142}$ the look within forced Americans to rethink the reasons underlying the exclusion of blacks from the suffrage.

White male suffrage advocates argued that black men had none of the qualities that entitled them to the franchise. ${ }^{143}$ The "minds of the blacks are not competent to vote," Samuel Young of New York asserted indignantly. ${ }^{144}$ They "had not the requisite intelligence [or] integrity," according to Louis Wilson of North Carolina. ${ }^{145}$ Others made similar claims, arguing that blacks were "a peculiar people, incapable . . of exercising [the] privilege [of voting] with any sort of discretion, prudence, or independence." 146 Unlike white men, John Ross asserted in 1821, black men had "no just conceptions of civil liberty," nor did they know "how to appreciate it."147 Consequently, they were "indifferent to its preservation." 148 Young argued that blacks were "too much degraded to estimate the value, or exercise with fidelity and discretion that important right," 149 adding that the vote "would be unsafe in their

138. The proposition to limit suffrage to whites passed by only five votes. See PROCEEDINOS AND Debates of the Convention of NoRTH-Carolina, Called To amend the Constitution of the State, Which ASSEmbled at RaLeigh, JUNE 4, 1835, at 80 (Raleigh, Joseph Gales \& Son 1836) [hereinafter NORTH CAROLINA CONVENTION OF 1835].

139. See Leon F. LITWACK, NORTh of Slavery: The Negro IN the Free STATES, 1790-1860, ut $75-79$ (1961).

140. See FIELD, supra note 136, at 43-52.

141. See Eugene H. Berwanger, The Frontier against Slavery: Western anti-Neoro PREJUDICE AND THE SLAVERY EXTENSION CONTROVERSY (1967) (detailing the antiblack laws in the western and midwestern states during the antebellum period); ROBERT R. DYKSTRA, BRIGHT RADICAL STAR: BLACK FREEDOM AND WHITE SUPREMACY ON THE HAWKEYE FRONTIER passim (1993) (telling the story of the struggle for black suffrage in Iowa); Tom LeRoy McLaughlin, Popular Reactions to the Idea of Negro Equality in Twelve Nonslaveholding States, 1846-1869: A Quantitative Analysis 37-38 tbl.I (1969) (unpublished Ph.D. dissertation, Washington State University) (on file with the Washington State University Library) (detailing the outcome of 19 state referenda on black suffrage from 1846 to 1869). Useful surveys of black suffrage during this period include: LITWACK, supra note 139, at 74-93; EMIL Olbrich, The Development OF SENTIMENT ON NEgro SufFrage to 1860 (Negro Univ. Press 1969) (1912); James Truslow Adams, Disfranclisement of Negroes in New England, 30 AM. Hist. Rev. 543 (1925); and Charles H. Wesley, Negro Suffrage in the Period of Constitution-Making, 1787.1865, $32 \mathrm{~J}$. NEGRO HIST. 143 (1947).

142. See Lemons \& McKenna, supra note 134, at 30.

143. On the conception of blacks as innately inferior, see GEORGE M. FREDRICKSON, THE BLACK IMAGE IN THE WhITE MIND: THe Debate ON AFro-AMERICAN Character and Destiny, 1817-1914, at 43-96 (1971); and JAMES M. MCPHERSON, THE STRUGGLE FOR EQUALITY: ABOLITIONISTS AND THE, NEGRO IN THE CIVIL WAR AND RECONSTRUCTION 134-53 (1964).

144. NEW YORK CONVENTION OF 1821, supra note 45, at 191 (statement of Samucl Young).

145. NORTH CAROLINA CONVENTION of 1835, supra note 138, at 80 (statement of Louis D. Wilson).

146. NEW YORK CONVENTION OF 1821, supra note 45, at 180 (statement of John Ross).

147. Id.

148. Id.

149. Id. at 191 (statement of Samuel Young). 
hands." 150 They composed "[o]ne half of the tenants of our jails and penitentiaries," John Sterigere, a delegate to Pennsylvania's convention, announced conclusively. ${ }^{151}$ While white men were inherently independent and resistant to every temptation to sacrifice their vote, a black man's vote "would be at the call of the richest purchaser," warned Samuel Young. ${ }^{152}$

There were others who bypassed the question of capacity altogether and denied that blacks could ever vote because they were not citizens. With arguments that would reappear nearly twenty years later in Dred Scotl $v$ Sandford, ${ }^{153}$ Pennsylvanians, for instance, asserted in their constitutional convention that blacks were slaves and not citizens when the Declaration of Independence asserted that all men were created equal. ${ }^{\text {sid }}$ Neither the state's Gradual Abolition Act of $1780^{155}$ nor either of Pennsylvania's previous constitutions ${ }^{156}$ granted blacks citizenship, these delegates argued. Therefore. blacks had no grounds to exercise the vote.

Defenders of black suffrage countered on two grounds. Some who were pessimistic about the possibility of enfranchising all blacks argued that property gave some black men the qualifications to vote. In Norh Carolina, for instance, defenders of black suffrage argued that it was "a strange anomaly in a republick to deny to any free citizen the privilege of voting, and at the same time acknowledge that he is free, and tax him as such." ${ }^{157}$ It was not "right and just in us as men and as republicans," one author argued, "to disenfranchise a whole class of freemen, who contribute to an equal proportion to the support of the Government."1.18 This author invoked the principle of "taxation and representation, or the right not to be deprived of your property save of your own consent": This principle, the author argued, was "sacred and just in itself," even for blacks, and the violation of this principle would have tarnished the American system. ${ }^{159}$ Only prejudice, another author argued, led to the objection "that free blacks are too corrupt and ignorant to exercise the

150. Id.

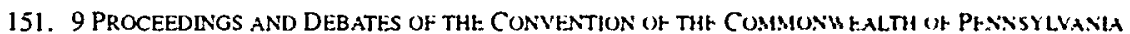

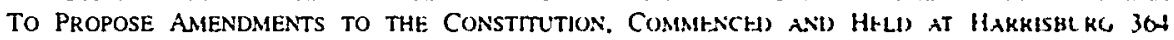

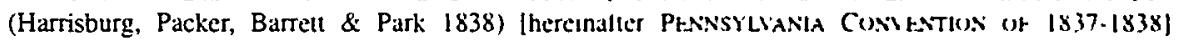
(statement of John Sterigere).

152. NEW YORK CONVENTION OF 1821. supra nole 45. al 191 (stalement of Samuel Young) On popular white opinion in North Carolına against contunued black ent tanchusement, sec (HakLotTr J. July

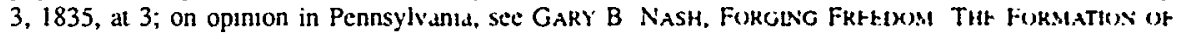
PHILADELPHIA'S BLACK COMNUNITY, 1720-1840. dt 223-27 (1988)

153. 60 U.S. (19 How) 393, 406-27 (1857)

154. See 9 PENNSYLVANIA CONVENTION OF 1837-1838. supra nute 151. a 323.30 istaliement of E $M$ Sturdevant); see also id. at 356-67 (statement of John Stengerel

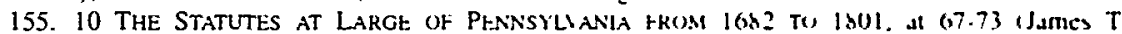
Mitchell \& Henry Flanders eds , 1904)

156. See PA. CONST. of 1790; PA CONST of 1776

157. Conventon, Newbern SPECTATOR \& POL Rto (.Nonh Catulinal. June 19, 1535. al 3

158. Madison, N.C. J. (Fayetteville), June 24, 1835. At 3

159. Id.; see also FAYETTEVILLE OBSERVter, June 16, 1835, at 3 ("There is, so tat ds we can ledrn. a general feeling of regret in this community at the total disentranchisement of the tree coloured people ") 
right [to vote] for the common weal."160 The ownership of property demonstrated that there were "many of them who make the very best citizens and mechanics, and whose intelligence is far above the standard of mediocrity." 161 Therefore, "those who possess such a freehold, which is seldom or never obtained except by the worthy, ought, for the sake of justice and good policy,... be distinguished from the others." 162 This argument worked only in New York, where blacks retained the vote in the constitutions of 1822 and 1846 , so long as they owned a substantial amount of property. ${ }^{163}$ Elsewhere, the attempt to use property ownership to rebut the presumption of black incapacity failed. ${ }^{164}$

Recognizing that property arguments were no longer convincing, black suffrage advocates often used capacity-based arguments instead. Blacks meeting in their own state conventions ${ }^{165}$ and their white advocates in state constitutional conventions argued that "[t]he mere possession of property was ... no test of political merit." 166 Consequently, "if political privileges were extended to [a black man's] race, they should not depend on his possessions, but on his manhood."167 Benjamin F. Bruce of New York argued that "the truth [is] self evident that 'all men are created equal," and sought to "reduce to practice what we all hold most tenaciously in theory." 168 If it were true, he said, that "colored persons' are men then give them the rights and privileges of men." 169 But "if they are not men, then make them slaves, chattles and things, and let us have no more of this 'opposition to slavery' and desire 'to benefit the colored man' that is so much talked in favor of and voted against." 170 Or as Thomas Foster of Minnesota argued in 1857, "Complexion has nothing to do with a man's mental capacity; nothing to do with his political efficiency; and nothing to do with his ability to serve the State, either in the councils of the nation, or upon her battle fields." 171

160. Smith, N.C. J. (Fayetteville), July 1, 1835, at 3.

161. Id.

162. Id.

163. See FIELD, supra note 136, at 29, 53.

164. See, e.g., NoRTh CaRolina Convention of 1835, supra note 138, at $69-70$ (statement of Nathaniel Macon); id. at 71 (statement of Richard D. Spaight).

165. See, e.g., MEMORIAL. TO THE HONORABLE tHE SENATE AND House of REPRESENTATIVEs of THE COMmonwealth OF PENNSYlvania, IN GENERAL ASSEMBly MET 6 (n.p. 1855) (noting that the black population "compares favorably with the white population in intelligence, and morality"). See gentrally Proceedngs of THE Black State Conventions, 1840-1865 (Philip S. Foner \& George E. Walker eds., 1979) (printing the proceedings of the antebellum black state conventions).

166. NEW YORK CONVENTION OF 1846, supra note 123, at 1027 (statement of John A. Kennedy).

167. $I d$.

168. Id. at 1016 (statement of Benjamin F. Bruce).

169. Id.

170. Id.

171. Debates and Proceedings of the Constitutional Convention for the terkitory of Minnesota, TO Form a STATE CONSTITUTION PREPARATORY to ITS ADMISSION wTO THE UNION AS A STATE 341 (St. Paul, George W. Moore 1858) (statement of Thomas Foster). 
This argument over the nature of black intelligence continued in the congressional debate on the Fifteenth Amendment. The proponents of the Amendment asserted that "[i]ntellect, and not wealth" should be the sole criterion for the suffrage. ${ }^{172}$ As Senator Adonijah S. Welch of Florida pointed out:

[I]ntelligence and virtue are not the distinctive characteristics of races; they are not peculiar to any race; they are not monopolized by nor wholly excluded from any people on the round earth. Intelligence and virtue are individual possessions, inconstant qualities varying ad infinitum among the individuals of every people . . . Those constant qualities which mark the different races are mainly physical, consisting of peculiarities of color, feature, figure, and the like; but as these peculiarities are not the qualifications for the voter, nor indicate the presence or absence of such qualifications, they cannot without absurdity be assumed as the ground for withholding or bestowing the right of suffrage. ${ }^{173}$

Opponents of black suffrage replied using similar terms. Senator George Vickers of Maryland claimed that "[t]he negro as a class, as a race, is unfortunately ignorant and superstitious .... He needs the very qualities and qualifications essential to a free, fair, and sensible exercise of the elective franchise."174 The Fifteenth Amendment gave blacks the vote on paper, but this achievement hardly demonstrated a metamorphosis in people's beliefs. ${ }^{175}$ Deprived of the weapons of racial classifications, southern Democrats quickly and successfully resorted to other techniques, such as literacy tests and poll taxes, to impede black access to the polls. ${ }^{176}$

172. Cong. Globe, 40th Cong., 3d Sess. 690 (1869) (stalement of Rep Beck)

173. Id. at 982 (statement of Sen. Welch).

174. Id. at 911 (statement of Sen. Vickers).

175. See ERIC FONER, RECONSTRUCTION: AMERICA'S UNFINISHED REVOLUTION, 1863-1877, al $\$ 47$ (1988) ("II]t was not a limited commitment to blacks' nghts. but the desire to tetain other inequalities. affecting whites, that produced a Fifteenth Amendment. "): FREDRICKSON, supra note 143, at 183 ("What made Negro suffrage in the South acceplable to the North by 1867 was nol a profound belief in the black man's capacity for intelligent citizenship but the poltucal necesstucs of restructunng the Union under Northem or Republican hegemony."); WILLIAM GILLETTE, THE RIGHT TO VOTE. POLmics ANi) THE PASSAGE OF THE FIFTEENTH AMENDMENT 165 (1965) (arguing thil Republicans favored the Fifteenth

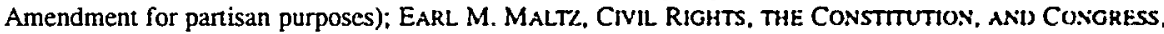
1863-1869, at 156 (1990) (noting that the drafters of the Amendment "understoud thut the only new requirement they were adding was that any qualification for voung has to be applied equally to all races [and that s]uch a requirement might have litue practical impact"): $X_{1}$ Wang. Black Suffrage and the Redefinition of American Freedom, 1860-1870. 17 CARDOzo L. REV 2153, 2222-23 (1996) (argutng that the Fifteenth Amendment was a compromise measurc). But see McPHERsoN. supra note 143. at $417-32$ (portraying the Fifteenth Amendment as the culmuation of the abolituonist struggle). LuWands Cox \& John H. Cox, Negro Suffrage and Republican Polincs: The Problem of Monvanon in Reconstruction Historiography, 33 J.S. HIST. 303, 330 (1967) (arguing that Republicans were mouvated by pnnitiple)

176. See generally J. MORGAN KOUSSER, THE SHAPING OF SOUTHERN POLITICS SUFFige RESTRICTION AND THE ESTABLISHMENT OF THE ONE-PARTY SOUTH. 1880.1910 (1974) (detanling the concerted effort to disenfranchise blacks in the South at the turn of the century): XI WANG. THE TRLAL Of DEMOCRACY: BLACK SUFFRAGE AND NORTHERN REPUBLICANS. 1860.1910 (1997) (detalling the fallure 


\section{CONCLUSION: INSIDE OUT}

Although today we equate political rights, like suffrage, with citizenship, ${ }^{177}$ thereby disenfranchising aliens, ${ }^{178}$ the nineteenth century stressed the inner character and capacity of persons. This is not to say that property qualifications, like the poll tax, disappeared entirely; they did not. ${ }^{179}$ The focus of the suffrage debate, however, had shifted radically. William Greene of Massachusetts put the nineteenth-century perspective well: "No living creature can be recognized as one of the people, if that living creature has not rational faculties by which it can either consent or refuse to become the subject of government." I80 "[o]xen and horses cannot give their consent to government," Greene continued, "neither can madmen, idiots, or immature children give their consent; and therefore, it follows, on account of this natural incapacity, that none of these can be recognized as people."181 The look within often ended in an evaluation of the qualities of the mind, as in James R. Leib's (by then) uncontroversial assertion in an 1839 pamphlet "that the intellect of society does not reside, exclusively, with the monied men," 182 or in Samuel Jones's contention that only those who had

of federal enforcement of the Fifteenth Amendment).

177. This is a far cry from the 19th-century distinction of political rights, like suffrage, and civil rights, like citizenship, as exemplified by Minor v. Happersett, 88 U.S. (21 Wall.) 162, 176 (1874), which upheld Missouri's restriction of the vote to males and denied the identity of citizenship rights and voting rights. Still, the equation today is not perfect, as the disenfranchisement of felons and insane persons in many states attests. See infra notes 190,194 . On the importance of voting to citizenship, see JUDTTH N. SHKLAR, AMERICAN CTTIZENSHIP: THE QUEST FOR INCLUSION 25-62 (1991).

178. The 19th century, on the whole, felt comfortable enfranchising aliens. See Gerald L. NeumaN, STRANGERS TO THE CONSTITUTION: IMMIGRANTS, BORDERS, AND FUNDAMENTAL LAW 63-70 (1996). In 1926, Arkansas became the last state to disenfranchise aliens. See Leon E. Aylsworth, The Passing of Alien Suffrage, 25 AM. POL. SCI. REv. 114 (1931). A number of recent articles have advocated the enfranchisement of aliens. See, e.g., Gerald L. Neuman, "We Are the People": Alien Suffrage in Germon and American Perspective, 13 MICH. J. INT'L L. 259 (1992); Jamin B. Raskin, Legal Aliens, Local Citizens: The Historical, Constitutional and Theoretical Meanings of Alien Suffrage, 141 U. PA. L. REV. 1391 (1993); Gerald M. Rosberg, Aliens and Equal Protection: Why Not the Right To Vote?, 75 MiCH. L. RBV. 1092 (1977).

179. A version of the Fifteenth Amendment proposed by Senator Henry Wilson failed. This version would have abolished qualifications for voting and office holding based on "race, color, nativity, property, education, or religious belief." See GILLETTE, supra note 175, at 59 (quoting CONG. GLOBE, 40th Cong.. 3d Sess. 1029 (1869)). The poll tax qualification for federal elections was outlawed by the Twenty-Fourth Amendment in 1964 and declared unconstitutional for state elections in Harper v. Virginia Board of Elections, 383 U.S. 663 (1966). See generally DUDLEY O. MCGOVNEY, THE AMERICAN SUFFRAGE MEDLBY $110-80$ (1949) (advocating the abolition of the poll tax).

It is important to note as well that the decline in the significance of property in the context of voting rights in the 19th century did not lead to a representational system of "one person, one vote." Property (is well as other interests) maintained its disproportionate influence in the apportionment of representative districts until Reynolds $v$. Sims, 377 U.S. 533 (1964), which held that legislators represent people and not areas and that legislative districts must be apportioned, as nearly as practicable, on the basis of equal population.

180. 2 MASSACHUSETTS CONVENTION OF 1853, supra note 92, at 726 (statement of William Greene).

181. Id.

182. JAmes R. LeiB, ThoughtS on the Elective Franchise 14 (Philadelphia, John C. Clark 1839). 
"intelligence and honesty" deserved the vote. ${ }^{183}$ Whereas the eighteenth century looked to property for guidance in determining a person's fitness to vote, the nineteenth century turned to the soundness of a person's mind.

But where did this logic end? If intelligence was truly the best test of capacity, should there not be an educational requirement? So thought Samuel Jones. ${ }^{184}$ And although few others agreed, anxiety about a poorly educated electorate fueled the movement for public education. ${ }^{185}$ Perhaps, instead, one should look to a person's age? So thought James Leib, who suggested raising the voting age to thirty-three, which he called the "age of reflection." 186 Or better yet a literacy requirement? So thought legislators in Connecticut and Massachusetts, who, eager to disenfranchise a growing immigrant population in the 1850 s, adopted such provisions. ${ }^{187}$ By the early twentieth century, seven southern states and nine western states had followed suit. ${ }^{18 s}$ Perhaps paupers should be disenfranchised since failure to work might indicate a lack of capacity? So thought the fourteen states that had enacted such provisions by the end of the nineteenth century. ${ }^{189}$ Certainly, then, a felony conviction indicated a lack of the requisite sensibilities. So thought the nineteen states that disenfranchised felons by the Civil War. ${ }^{190}$ Or what about the insane, who,

183. Samuel Jones, a treatise on the Right of Surtrage 89 (Bosion. Ous. Bruidets $\&$ Co 1842).

184. See id. at 128-34.

185. See David W. Robson, Educating Republicans 251-52 (1985)

186. LEIB, supra note 182, at 17. See generally. WENDELL W CULTIC, YOUTH's BatTL: FOR THE BALLOT (1992) (providing a history of voting age requirements)

187. See CONN. CONST. of 1818, amend. XI (1855). MASS CONST amend XX (1857). TYLEk ANBINDER, NATIVISM AND SLAVERY: THE NORTHERN KNON NOTHINGS AND THF POLmTS OF THE $1850 \mathrm{~s}$. at 138, 248-52 (1992).

188. See KouSSER, supra note 176, at 55 tbl 21 . MiCGovNeY, supra nutc 179, \& 59.60. Arthur W Bromage, Literacy and the Electorate, 24 AM POL SCI REv 9.16 (1930) Literacy lests were upheld, under minimum scrutiny, in Lassiter : Northampton Counn Board of Electrons. 360 U S 45. 51 (1959). because. as the Cour noted, "[t]he ability to read and write. has some relution to standarus designed to prumute intelligent use of the ballot." Congress, however. prohibited such tests in the Voung Rights Act Amendments of 1970, Pub. L. No. 91-285. 84 Stat. 314. 315 (codified as amended at 42 L'SC \$ 19736 (b)-(c) (1994)). See also Oregon v. Mitchell, 400 U S 112. 118 (1970) (upholdıng the literacy test provisions of the Voting Rights Act Amendments of 1970)

189. See Steinfeld, supra note 2, at 335 Steinleld concludes that in the early 1 th century the "republican precept that only the self-governing should excresse political duthonty was recist [with] the liberal idea that the self-governing were those who owned and disposed of themselses "Id al 375 Steinfeld's aricle now serves as the conventuonal wisdom See, e $g$, James A Henreta. The Rise and Decline of "Democratic Republicanism": Polutical Rights in New York and the Seteral Siases, 1800-1915. 53 ALB. L. Rev. 357, 369 (1989) (citing Steinfeld). Steinfeld's labor theory of suffrage is part of the story. but not the full story. The theory's most obvious shortcoming is tis fatlure to clarify other restnctuons. such as those based on race and sex.

190. See PORTER, supra note 2 , at 148 bbl.III Fourteen stutes currendy disenfranchise telons lor lile See Jesse Furman, Note, Political Mlliberalism: The Paradox of Disenfranchusenten and ihe dunburalenees of Rawlsian Justice, 106 YALE L.J. 1197, 1217 n 125 (1997) (histung the pertunent constututunal and statutory provisions). There have been a number of discussions of disenfranchisement of telons since Richardson $v$. Ranirez, 418 U.S. 24, $41-56$ (1974). which upheld disenfranchesement of feluns under Section 2 of the Foureenth Amendment. See, e.g.. Note. The Disenfranchusement of Ex-Felons Cithzenship. Criminality; and "The Purity of the Ballot Box," 102 HaRV L REV 1300 (1989) (arguing that felon disenfranchisement is illegitimate since its purpose is to define the boundanes of the communty by placing some outside those boundaries); Furman, supra (arguing for the repeal of felon disenfranchisement laws 
by definition, lacked the requisite mental capacity? So thought a number of states: Massachusetts disenfranchised those under guardianship in $1821,{ }^{191}$ Virginia disenfranchised persons of "unsound mind" in $1830,{ }^{192}$ and within the next thirty years, eleven other states followed suit. ${ }^{193}$ After the Civil War and into the twentieth century, insanity provisions became commonplace in new and amended constitutions. ${ }^{194}$ Americans pursued the logic of the look

on the basis of their illiberalism); Gary L. Reback, Note, Disenfranchisement of Ex-Felons: A Reassessment, 25 STAN. L. REV. 845, 858-60 (1973) (criticizing felon disenfranchisement on Eighth Amendment grounds); Andrew L. Shapiro, Note, Challenging Criminal Disenfranchisement Under the Voting Rights Act: A New Strategy, 103 YALE L.J. 537 (1993) (challenging felon disenfranchisement under the Voting Rights Act); see also Steven B. Snyder, Note, Let My People Run: The Rights of Voters and Candidates Under State Laws Barring Felons from Holding Elective Office, 4 J.L. \& POL. 543 (1988) (finding state statutes barring felons from holding elective office unconstitutional under the Equal Protection Clause).

191. See MASS. CoNST. amend. III (1821).

192. VA. CONST. of 1830 , art. III, $\S 14$.

193. See Cal. Const. of 1849 , art. II, $\S 5$; Del. Const. of 1831 , art. IV, $\S 1$; lowa Const. art. II, $\S 5$ (1857); IOWA CONST. of 1846, art. II, § 5; KAN. CoNST. art. V, § 2 (1859) (amended 1974); MD. CONST. of 1851, art. I, § 5; MINN. CONST. art. VII, § 2 (1857) (amended 1974); N.J. CoNST. of 1844, art. II, § 1; OHIO CONST. art. V, § 6 (1851); OR. CONST. art. II, $\S 3$ (1857) (amended 1944); R.I. CoNST. art. II, § 4 (1842) (amended 1950); WIs. CONST. art. III, § 2 (1848) (amended 1986). Virginia retained the clause in its 1851 constitution. See VA. ConST. of 1851 , art. III, $\$ 1$. Ninetcenth-century constitutionmakers did not differentiate between varieties of mental illness. They used a number of words interchangeably, such as "lunatic," TEX. CONST. art. VI, § 1, cl. 2 (1876) (amended 1932); "insane," WIS. CONST. art. III, § 2 (1848) (amended 1986); "idiot," WYO. CONST. art. VI, \$ 6 (1889) (amended 1996); and "non compos mentis," id. This lack of precision has persisted in modern constitutions. See BRUCE DENNIS SALES ET AL., DISABLED PERSONS AND THE LAW 100 (1982) (noting the variation in terminology).

194. See, e.g., ALA. CONST. ant. VIII, $\$ 182$ (1901) (amended 1996); ALA. ConsT. of 1875, art. VIII, $\S 3$, cl. 2; ARK. CONST. art. III, $\$ 5$ (1874); ARK. CONST. of 1868, art. VIII, $\$ 3$, cl. 6; DEL. CoNST. art. V. $\S 2$ (1897); FLA. CONST. of 1886, art. VI, $\$ 4$; FLA. CONST. of 1868, art. XV, $\S 2$; GA. CONST. of 1877 , art. II, $\S 2$, cl. 2; GA. CONST. of 1868, ant. II, § 6, cl. 2; IDAHO CONST. art. VI, § 3 (1889) (amended 1950); KY. CONST. $\S 145$, cl. 3 (1891) (amended 1955); LA. CONST. of 1879, art. 187; MD. CoNST. art. 1, $\S 2$ (1867) (amended 1972); MD. CONST. of 1864, art. I, § 3; MISS. CoNST. art. XII, $\$ 241$ (1890) (amended 1935); Miss. CONST. of 1869, art. VII, $\S 2$; MO. CONST. of 1875 , art. VIII, $\S 8$; MONT. ConST. of 1889 , art. IX, § 8; NEB. CONST. art. VII, § 2 (1875); NEv. CoNST. art. II, § 1 (1864) (amended 1880); N.J. CONST. art. II, II 6 (1947) (amended 1995); N.M. CoNST. art. VII, 11 (1911) (amended 1967); N.D. CoNST. art. V, $\$ 127$ (1889) (amended 1978); OKLA. CONST. art. III, $\$ 1$ (1907) (amended 1918); S.C. CoNST. art. II, $\S 6$, cl. 2 (1895) (amended 1971); S.D. ConST. art. VII, \& 8 (1889) (amended 1974); TEX. ConST. art. VI, $\S 1$, cl. 2 (1876) (amended 1932); TEX. CONST. of 1869, art. VI; UTAH CONST. art. IV, $\S 6$ (1895) (amended 1975); W. VA. CONST. art. IV, $\$ 1$ (1872) (amended 1994); W. VA. CoNST. of 1863, art. III, $\S$ 1; WYO. CONST. art. VI, § 6 (1889) (amended 1996).

Until recently, nearly every state prohibited "mental incompetents" from voting, cither by constitution or by statute. See RICHARD C. ALLEN ET AL., MENTAL IMPAIRMENT AND LEGAL. INCOMPETENCY 364-67 (1968) (reviewing the case law); THE MENTALLY DISABLED AND THE LAW 333-40 (Samuel J. Brakel \& Ronald S. Rock eds., rev. ed. 1971) (reviewing constitutional and statutory provisions in chart form); SALES ET AL., supra note 193, at 101-04 (same); Joseph F. Vargyas, Voting Rights and Jury Duty, in 3 LEOAL RightS OF MENTALly DiSABled PERSONS 1771, 1771-81 (PLI Litig. \& Admin. Practice Criminal Law \& Urban Problems Course Handbook Series No. 116, 1979) (reviewing the case law); Robert W. Stockstill, Comment, Voting and Election Law in the Louisiana Constitution, 46 LA. L. REv. 1253, 1258-60 (1986); Joel E. Smith, Annotation, Voting Rights of Persons Mentally Incapacitated, 80 A.L.R.3d 1116, 1116-33 (1977) (same). For recent developments, see BARBARA A. WEINER, Rights of Institutionalized Persons, in SAMUEl JaN BRAKEl ET AL., THE MENTALLY DISABLED AND THE LAW 251 (3d ed. 1985). Weiner writes: "While disenfranchisement of the mentally disabled was common in the past, today statutes in a number of states secure the vote to such individuals." Id. at 259.

While occasional dicta in the 1970s suggested that disenfranchisement of the mentally disabled was constitutional, see, e.g., Shepherd v. Trevino, 575 F.2d 1110, 1115 (5th Cir. 1978) (comparing felons with "insane persons [who] have raised questions about their ability to vote responsibly"); Kronlund v. Honstein. 327 F. Supp. 71, 73 (N.D. Ga. 1971) (noting the state's interest in "preserving the integrity of her clectoral 
within as far as it would take them, to root out every "biological breach of the social compact."

These categorical exclusions, however, were the exceptional cases-the evaluation of the average person's inner self was a more difficult proposition. Several popular nineteenth-century movements claimed to offer pseudoscientific certainty in analyzing a person's mental and moral capacities. The search for such easy answers offers a partial explanation for the appeal of phrenology, which claimed that the shape of a person's head revealed their intellectual and moral character. ${ }^{196} \mathrm{~A}$ host of more mainstream scientists, such as Louis Agassiz and Samuel George Morton, went on to "prove" in their

process by removing from the process those persons with proven anti-social behavior whase behsusor can be sald to be destructuve of society"s ams," and dexlaring that "a Siale ms) prohibil udiuls and insane persons... from participating in her elections"). it is unclear how the Supreme Coun would rule tuxlay on an equal protection challenge to insanity clauses given tis decision in Cav of Cleburne 1 Cleburne Living Center, 473 US. 432 (1985) Cleburne held that mental retardation is nut 1 quast-suspect classification, see id. al 442, but rejected a ban on group homes under a ratuonal basis standaru. ser al at 450. Both before and after Cleburne, commentators argued that mental illness should be trealed as a suspect classification under equal protection doctrine and that, consequently. mental disubility restructions on

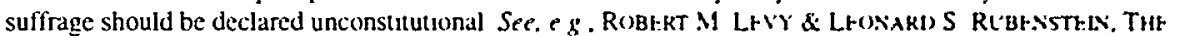
RIGHTS OF PEOPLE WITH MENTAL DISABILITILS 293 \& nn 50-51 (1996) (arguing that institulionulied persons have a constitutional right to vole). Steven $\mathrm{K}$ Mcteslt. Comment. The Right To Vote of the Mentally Disabled in Oklahoma: A Case Studv of Overmclustse Language and Fundantental Rughtus, 25 TULSA L.J. 171 (1989) (urging that stnct scrutuny be applied to render unconsitutuonal statutes that prohibit the mentally ill from voting); Note, Mental Disabilin and the Right To Vote, 88 YALt L. I lG4t (1979) (same); Note, Mental Illness: A Sispecr Clossification'. 83 YALt L J 1237. 1267 (1974) (argurng that mental disability restrictions volate equal protection)

195. Rober L. Hayman, Jr., Presumphons of Jushce Las, Poliucs, and the Hentall, Returded Parent. 103 HaRV. L. REV 1202, 1204 (1990); see also Martha Minow. Mlaking all tit. Dirfrkexct INCLUSION, EXCLUSION, AND AMERICAN LAW' 121-28 (1990) (delinealing the legal history of competence and incompetence).

196. Phrenologists, like Elisha P Hurlbut, did not miss the connections between phrenology's biological discoveries and politucal reform In his Essays on Humen Rights and Nieur Poltrical Guaranues. Hurlbut argued that all who had the proper "intelhgence and moral impulse" deserved the vute E P HuRlbut, Essays on Human Rights and Thtik Political Glakantiks IOM (New Yurk, Greeley \& McElrath 1845) By the same token. all those "whose moral and intellectual tacultes ate immature" (children), "whose intellectual perceptions are so disordered as to Jepan from the standard of truth and reason" (the insane), "whose moral natures are so defectuve as that thet impulses are chielly in tavor ot the licentious indulgence of their animal desires" (Ielons). and those "grussly ignorant and unenlightened" (the illiterate) should "be excluded from a participation an Govemment " Id at $111-12$ (emphasis umilled) Using these rules, Hurlbut argued that women should be dllowed la vote since thetr natures diltered enough from men that they could not adequatcly be represented See ted at 112.23 It is no wunder, then. that Elizabeth Cady Stanton and Susan B. Anthony, in thetr Histon of Woman Suffrage. Iisted phrenology together with the Protestant Reformation. Quakensm, and transcendentalism as among the major revelations of science, religion, and philosophy that led to the woman's nghts movement of the IVth century Ser I HISTORY OF WOMAN SUFFrage 51 (Elizabeth Cady Stanton et al eds. New York. Fuwler \& Wells 1881 ) Hurlbut did not address the question of black suffrage On Hurlbul, see Jemi D Davits. Priktsolucx. FAD AND SCIENCE 167 (1955); L. RAY GUNN. THE DECLINE OF AUTMORTT PUBLIC ECONOMIC POLICY AND POLITICAL DEVELOPMENT IN NEW YORK, 1800-1860. at 175-76 (1988), and I LEGAL AN1) JUticlal. HISTORY OF NEW YORK 403 (Alden Chester ed. 1911) On phrenulogy. sec R(xitk C(x)trk. THE

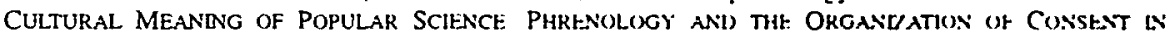

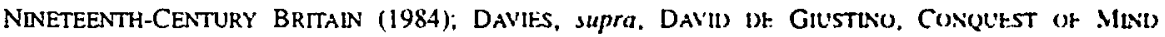
PHRENOLOGY AND VICTORLAN SOCIAL ThOUGHT (1975). ROBERT M YOUNG. MINI), BRAIS aNt) ADAPTATION IN THE NINETEENTH CENTURY 9-53 (1970), and Pierre Schlug. Lan and Phrenology, 110 HARV. L. REV. 877 (1997). 
studies of the human brain the intellectual inferiority of blacks and other races. ${ }^{197}$ On the basis of such pseudo-scientific claims, women and blacks continued to be disenfranchised. ${ }^{198}$ So it was that the look within possessed a sad irony: Americans, for all their searching inward, could not, in the end, help but look outward.

197. See Stephen Jay Gould, The Mismeasure of MaN 62-104 (rev. ed. 1996); William STANTON, THE LEOPARD'S SPOTS: SCIENTIFIC ATTITUDES TOWARD RACE IN AMERICA, 1815-59 (1960).

198. See, e.g., CONG. GloBE, 39th Cong., 1st Sess. 246 (1866) (statement of Sen. Davis) ("Camper, Soemmering, Lawrence, Virey, Ebel, and Blumenbach agree that the brain of the negro is smaller; and Gall, Spurzheim, and Combe, that it is so distributed as to denote less capacity for reasoning and judging than the Caucasian."); CONG. GLOBE, 38th Cong., 1st Sess. 2248 (1864) (statement of Sen. Cowan) ("I exclude a black man [from the suffrage] because black is the evidence that he is an inferior man ...."); William A. Hammond, Woman in Politics, 137 N. AM. REv. 137, $141-42$ (1883) ("The brain of woman is . . different from that of man, and difference of structure necessarily involves difference of function."). It is important also to note that many of the capacity qualifications blended together. For instance, blacks were considered more likely to be insane than whites. See NORMAN DAN, CoNCEPTS OF INSANITY IN THE UNITED STATES, 1789-1865, at 104-08 (1964). 